\title{
Efektivitas PBL setting TTW dan TPS ditinjau dari prestasi belajar, berpikir kritis dan self-efficacy siswa
}

\author{
Wahyu Hardiyanto ${ }^{1}$, , Rusgianto Heri Santoso ${ }^{1}$ \\ ${ }^{1}$ Program Studi Pendidikan Matematika, Program Pascasarjana, Universitas Negeri Yogyakarta. \\ Jalan Colombo No. 1, Karangmalang, Yogyakarta 55281, Indonesia. \\ * Corresponding Author. Email: wahyuhardiyanto.aan@gmail.com \\ Received: 5 October 2016; Revised: 20 February 2018; Accepted: 2 May 2018
}

\begin{abstract}
Abstrak
Penelitian ini bertujuan untuk mendeskripsikan keefektifan pendekatan problem-based learning (PBL) setting think talk write (TTW) dan problem-based learning (PBL) setting think pair share (TPS) serta mendeskripsikan perbedaan keefektifan antara PBL setting TTW dan PBL setting TPS ditinjau dari prestasi belajar, kemampuan berpikir kritis dan self-efficacy siswa. Penelitian ini merupakan penelitian eksperimen semu. Instrumen yang digunakan untuk mengumpulkan data adalah tes prestasi belajar, tes kemampuan berpikir kritis dan angket self-efficacy siswa. Data yang dikumpulkan dianalisis dengan menggunakan one sample $t$-test, dan analisis multivariat (MANOVA). One sample t-test dilakukan untuk menguji keefektifan pendekatan PBL setting TTW dan keefektifan pendekatan PBL setting TPS, sedangkan analisis multivariat (MANOVA) dilakukan untuk menguji perbedaan keefektifan antara kedua treatment tersebut ditinjau dari prestasi belajar, kemampuan berpikir kritis dan self-efficacy siswa. Hasil analisis menunjukkan bahwa pendekatan PBL setting TTW dan pendekatan PBL setting TPS efektif ditinjau dari prestasi belajar, kemampuan berpikir kritis dan self-efficacy siswa. Selain itu hasil analisis multivariat menunjukkan bahwa tidak terdapat perbedaan keefektifan yang signifikan antara pendekatan PBL setting TTW dengan pendekatan PBL setting TPS ditinjau dari prestasi belajar, kemampuan berpikir kritis dan self-efficacy siswa.

Kata Kunci: problem-based learning, think talk write, think pair share, prestasi belajar siswa, berpikir kritis, self-efficacy

\section{The effectiveness of PBL Setting TTW and TPS seen from students learning achievement, critical thinking and self-efficacy}

\begin{abstract}
This study aims to describe the effectiveness of problem-based learning (PBL) setting think talk write (TTW) and PBL setting think pair share (TPS) and describe the difference of the effectiveness between PBL setting TTW and PBL setting TPS in terms of learning achievements, critical thinking ability and self-efficacy of grade students. This research is quasi-experimental research. The research instruments to collect the data are a learning achievement test, a test to examine the ability to think critically and a self-efficacy questionnaire. One sample t-test was conducted to examine the effectiveness PBL setting TTW and PBL setting TPS. Meanwhile, multivariate test (MANOVA) was carried out to determine the difference between PBL setting TTW and PBL setting TPS. The results show that both PBL setting TTW and PBL setting TPS are effective in terms of students learning achievements, critical thinking ability, and self-efficacy and there is no significant difference between the effectiveness of PBL setting TTW and the effectiveness of PBL setting TPS in terms of learning achievements, critical thinking ability and student self-efficacy.

Keywords: problem-based learning, think talk write, think pair share, academic achievement, critical thinking skills, self-efficacy

How to Cite: Hardiyanto, W., \& Santoso, R. (2018). Efektivitas PBL setting TTW dan TPS ditinjau dari prestasi belajar, berpikir kritis dan self-efficacy siswa. Jurnal Riset Pendidikan Matematika, 5(1), 116-126.

doi:http://dx.doi.org/10.21831/jrpm.v5i1.11127
\end{abstract}

Permalink/DOI: http://dx.doi.org/10.21831/jrpm.v5i1.11127 


\section{PENDAHULUAN}

Matematika sebagai suatu disiplin ilmu yang mengandalkan proses berpikir dipandang sangat baik untuk diajarkan pada anak didik. Di dalamnya terkandung berbagai aspek yang secara substansial menuntun murid untuk berpikir logis menurut pola dan aturan yang telah tersusun secara baku. Sehingga seringkali tujuan utama dari mengajarkan matematika tidak lain untuk membiasakan agar anak didik mampu berpikir logis, kritis dan sistematis. Hal Tersebut sejalan dengan Permendikbud No. 58 tahun 2014 (Mendikbud RI, 2014), bahwa mata pelajaran matematika perlu diberikan kepada semua peserta didik mulai dari sekolah dasar, untuk membekali peserta didik dengan kemampuan berpikir logis, analitis, sistematis, kritis, inovatif dan kreatif, serta kemampuan bekerjasama.

Memiliki kemampuan pikir dan tindak yang efektif dan kreatif dalam ranah abstrak dan konkret dapat dijadikan sebagai pengembangan dari yang dipelajari di sekolah secara mandiri. Hal inilah yang menuntut guru untuk melakukannya saat pembelajaran, yakni siswa dilatih dengan baik dalam membangun kemampuan dan keterampilan berpikir agar apa yang diharapkan guru berjalan dengan maksimal. Keterampilan berpikir diperlukan oleh siswa ketika dihadapkan pada suatu masalah yang harus segera dicari solusi permasalahannya.

Kemampuan berpikir adalah salah satu kecakapan hidup (life skill) yang perlu dikembangkan melalui proses pendidikan. Tentunya guru memegang peranan penting dalam proses pengembangan kemampuan berpikir kritis dan berpikir logis siswa. Sejalan dengan pendapat Basham, Irwin, Nardone, and Wallace (2011, p.1) bahwa fungsi pendidikan adalah mengajarkan seseorang untuk berpikir secara intensif dan berpikir kritis. Siswa yang memiliki kemampuan berpikir kritis tidak akan menerima secara seketika tentang sesuatu yang mereka liat dan dengar. Kemampuan berpikir kritis sangat penting dalam mempelajari materi baru dan mengaitkannya dengan apa yang telah siswa ketahui. Meskipun siswa tidak mengetahui semuanya, siswa dapat belajar untuk bertanya secara efektif dan mencapai kesimpulan yang konsisten dengan fakta.

Kemampuan berpikir kritis juga merupakan suatu hal yang amat penting dalam masyarakat modern, karena dapat membuat manusia menjadi lebih fleksibel secara mental, terbuka dan mudah menyesuaikan dengan berbagai situasi dan permasalahan. Berpikir kritis juga menjadi elemen penting bagi setiap orang untuk meraih sukses dalam kehidupannya. Seperti yang diuraikan oleh Mason (2008, p.2) "critical thinking is consistuted by particular skills, such as the ability to assess reasons properly, or to weight relevant evidence, or to identify fallacious argument". Maksudnya bahwa berpikir kritis didasari oleh ketrampilan tertentu, seperti kemampuan untuk menilai alasan yang benar, atau untuk menimbang bukti yang relevan, atau untuk mengidentifikasi argument yang keliru. Kemampuan berpikir kritis pada dasarnya merupakan kemampuan untuk dapat mempertimbangkan informasi-informasi yang diperoleh dengan tujuan dapat membuat keputusan tentang apa yang akan dilakukannya.

Akan tetapi, harapan ini tidaklah sejalan dengan fakta yang terjadi. Beberapa hasil riset terdahulu menunjukkan bahwa dalam pembelajaran matematika, siswa cenderung hanya menghafal sejumlah rumus, maupun langkahlangkah penyelesaian soal yang telah diajarkan atau dicontohkan oleh guru (Hendriana, 2009, p.3; Rohaeti, 2008, p.2). Akibatnya, apabila mereka diberikan soal yang berbeda dengan soal latihan, maka mereka bingung karena tidak tahu harus mulai dari mana mereka bekerja. Permasalahan lain ditunjukkan oleh rendahnya daya serap UN pada mata pelajaran matematika baik pada tingkat nasional maupun lokal. Rendahnya data serap tersebut mengindikasikan adanya kesulitan siswa dalam menyelesaikan soal UN. Hasil riset juga menunjukkan bahwa salah satu penyebab kesulitan tersebut adalah kesulitan dalam menyelesaikan soal berupa gambar maupun soal naratif (Retnawati, Kartowagiran, Arlinwibowo, \& Sulistyaningsih, 2017). Misalnya, daya serap UN mata pelajaran matematika tahun 2012 sampai 2015 pada mata pelajaran matematika, khususnya materi geometri, di SMP N 2 Selomerto, Kabupaten Wonosobo masih rendah.

Selain ranah kognitif seperti telah dipaparkan, ranah afektif juga perlu diperhatikan. Salah satu aspek afektif yang mempengaruhi kesuksesan belajar siswa adalah self-efficacy. Bandura (1995, p.2) mengemukakan bahwa self-efficacy berkenaan dengan keyakinan dalam kemampuan seorang siswa untuk mengatur dan melaksanakan serangkaian tindakan yang dibutuhkan untuk menghasilkan pencapaian yang diinginkan.

Akan tetapi, hasil observasi yang dilakukan oleh peneliti menunjukkan bahwa masih 
banyak siswa kurang percaya diri, meragukan kemampuan akademisnya, tidak berusaha mencapai nilai tinggi di bidang akademik. Ada siswa yang mengungkapkan rasa takut apabila guru memintanya untuk menjawab pertanyaan. Kasus lain, juga ditemukan siswa yang menghindari tugas-tugas sulit, melihat tugas-tugas sebagai rintangan, dan merasa rugi menyelesaikannya; usaha kurang optimal dan cepat menganggap sulit; mudah menyerah, malas, dan gelisah, terlihat ketika siswa mengikuti pelajaran tidak memperhatikan guru. Hal-hal tersebut mengindikasikan rendahnya self-efficacy siswa.

Salah satu faktor yang mempengaruhi rendahnya kompetensi kognitif, maupun afektif siswa seperti yang telah disinggung tersebut adalah proses pembelajaran. Artinya, kualitas pelaksanaan pembelajaran adalah salah satu kunci keberhasilan siswa. Semakin berkualitas pembelajaran yang dilaksanakan, maka semakin besar pula peluang siswa mencapai sejumlah kompetensi yang diharapkan.

Kemampuan berpikir siswa tentu tidak dapat diajarkan kepada siswa secara langsung (Retnawati, Djidu, Kartianom, Apino, \& Anazifa, 2018), tetapi harus dilatih selama proses pembelajaran. Hal yang sama juga berlaku dengan self-efficacy siswa, yang juga dapat tumbuh dan berkembang melalui serangkain proses pembelajaran. Melatih siswa berpikir dapat dilakukan dengan memberikan ruang atau kesempatan sebesar-besarnya bagi siswa untuk mengkonstruksi pengetahuannya selama proses pembelajaran (Djidu \& Jailani, 2017). Guru dapat menerapkan berbagai model, metode, dan strategi pembelajaran yang mendukung kondisi tersebut.

Salah satu alternatif yang dapat dipilih oleh guru adalah dengan menerapkan problem based learning (PBL). Dalam banyak sumber disebutkan bahwa PBL memiliki keunggulan terutama dalam melatih kemampuan berpikir siswa (Djidu \& Jailani, 2016; Jailani, Sugiman, \& Apino, 2017; Mokhtar, Tarmizi, Ayub, \& Nawawi, 2013; Susanto \& Retnawati, 2016; Tan, 2003), serta mengembangkan kompetensi siswa pada sejumlah ranah afektif seperti karakter (Jailani et al., 2017), komunikasi matematis (Ningrum, 2017).

Aktivitas pembelajaran dalam problembased learning diantaranya adalah kolaborasi, dan diskusi dalam kelompok. Suasana kooperatif dalam PBL merupakan salah satu faktor yang melatih kemampuan beprikir kritis siswa (Nezami, Asgari, \& Dinarvand, 2013, p.2). Oleh karena itu untuk memaksimalkan pelaksanaan PBL, settting pembelajaran kooperatif dapat digunakan untuk dapat melatih kemampuan berpikir tingkat kritis siswa.

Salah satu keuntungan dari pembelajaran kooperatif adalah siswa dapat memperdalam pemahamannya saat mereka berdiskusi dan bertukar ide dengan anggota kelompok. Cooperative learning dapat menguntungkan bagi siswa yang berprestasi rendah maupun tinggi yang mengerjakan tugas akademik bersama-sama. Mereka yang berprestasi tinggi mengajari teman-temannya yang berprestasi lebih rendah, sehingga yang berprestasi tinggi dapat semakin mengasah kemampuannya dan yang berprestasi lebih rendah merasa terbantu dalam proses belajarnya.

Proses belajar melalui cooperative learning diharapkan siswa lebih aktif menyalurkan pengetahuan, gagasan, dan menerima gagasan dari temannya. Siswa dalam kelompok akan belajar mendengarkan ide atau gagasan orang lain, berdiskusi setuju atau tidak setuju, menawarkan atau menerima kritikan yang membangun dan siswa merasa tidak terbebani ketika ternyata pekerjaan dalam menyelesaikan masalah bernilai salah.

Pendekatan Problem-Based Learning akan lebih efektif apabila disusun dalam pembelajaran kooperatif yang cocok untuk pendekatan tersebut. Pendekatan problem-based learning merupakan pembelajaran yang menitik beratkan pada kegiatan pemecahan masalah, dan masalah yang harus diselesaikan merupakan masalah yang belum jadi atau tidak terstruktur dengan baik (ill-structured problem), sehingga hal ini dapat menantang siswa untuk berpikir dan melakukan diskusi secara berkelompok. Oleh karena itu dibutuhkan model yang mendukung untuk kegiatan tersebut. Siswa dihadapkan pada masalah nyata atau masalah yang disimulasikan, siswa bekerja sama secara berkelompok untuk mengembangkan ketrampilan memecahkan masalah (problem solving), kemudian siswa mendiskusikan apa yang harus dilakukan dan bernegoisasi untuk mendapatkan jawaban dari masalah yang diberikan.

Diantara tipe model pembelajaran kooperatif yang cocok untuk pendekatan problembased learning adalah think talk write (TTW) dan think pair share (TPS) karena dalam prosedurnya kedua model tersebut memiliki kegiatan yang menuntut kerja sama siswa dalam memecahkan masalah dan menemukan sesuatu. Selain itu, think talk write (TTW) dan think pair 
share (TPS) mengandung langkah-langkah kerja sama dan penemuan. Berdasarkan prosedurnya, think talk write (TTW) dan think pair share (TPS) akan cocok untuk diterapkan pada pendekatan berbasis masalah atau problem-based learning karena terdapat langkah dimana guru dan siswa bersama-sama menyelesaikan masalah sehingga dapat memaksimalkan fungsinya dan dapat meningkatkan berpikir kritis juga selfefficacy siswa.

Arends (2012) berpendapat bahwa model pembelajaran TPS merupakan cara yang efektif untuk membuat variasi suasana pola diskusi di kelas. Hal ini disebabkan karena prosedur yang digunakan dalam model TPS memberi siswa lebih banyak berpikir, untuk merespons dan saling membantu antar sesama siswa. Penggunaan pendekatan problem-based learing setting pembelajaran kooperatif tipe think talk write (TTW) dan think pair share (TPS) akan ditujukan pada materi matematika yang memerlukan perhatian khusus agar dapat melihat keefektifannya ditinjau dari prestasi belajar, kemampuan berpikir kritis dan self-efficacy siswa.

Berdasarkan uraian tersebut, maka perlu dilakukan penelitian efektivitas problem-based learning $(P B L)$ setting model pembelajaran kooperatif tipe think talk write (TTW) dan think pair share (TPS) ditinjau dari prestasi belajar, kemampuan berpikir kritis dan self-efficacy siswa.

Dengan penelitian ini, diharapkan dapat melengkapi empiris tentang keefektifan pendekatan problem-based learning (PBL) setting model pembelajaran kooperatif tipe think talk write (TTW) dan think pair share (TPS) ditinjau dari prestasi belajar, kemampuan berpikir kritis dan self-efficacy (efikasi diri) siswa serta membuka kemungkinan untuk penelitian yang lebih lanjut tentang permasalahan sejenis. Selain itu, hasil penelitian ini diharapkan akan membantu sekolah dalam menyiapkan guru dan siswa agar mampu menciptakan lingkungan pembelajaran yang berpusat pada siswa.

\section{METODE}

Jenis penelitian ini adalah penelitian kuasi eksperimen (eksperimen semu). Adapun desain yang digunakan adalah nonequivalent groups pretest-posttest design. Penelitian ini dilakukan di SMP Negeri 2 Selomerto, Wonosobo. Penelitian ini dilaksanakan pada tanggal 21 Maret 2016 - 17 Mei 2016. Populasi dalam penelitian ini adalah seluruh siswa kelas VIII SMP Negeri
2 Selomerto, Wonosobo tahun ajaran 2015/2016 yang berjumlah 8 kelas. Dengan menggunakan teknik pengundian secara random dari 8 kelas diperoleh kelas VIII-G dipilih sebagai kelompok dengan perlakukan berupa pendekatan ProblemBased Learning setting Think Talk Write (TTW), sedangkan kelas VIII-H diberikan perlakukan berupa pendekatan Problem-Based Learning setting Think Pair Share (TPS)

Data dalam penelitian ini diperoleh dengan pemberian tes prestasi belajar, tes kemampuan berpikir kritis, dan pengisian angket self-efficacy siswa. Instrumen yang digunakan adalah instrumen tes prestasi belajar, tes kemampuan berpikir kritis, dan angket selfefficacy siswa. Dari segi validitas, validitas instrumen berupa validitas isi dengan meminta saran, masukan, serta pertimbangan dari dua dosen ahli (expert judgment) dibidang materi dan evaluasi dan validitas konstruk pada angket. Setelah divalidasi isi instrumen tersebut di ujicobakan di kelas IX. Ujicoba instrumen penelitain ini diberikan kepada siswa kelas IX SMP Negeri 2 Selomerto, Wonosobo yang berjumlah 30 siswa untuk tes prestasi belajar baik untuk pretest maupun post-test, 30 siswa untuk tes kemampuan berpikir kritis baik pretest maupun posttest dan 60 siswa untuk angket self-efficacy siswa. Hasil uji coba instrumen dapat membantu estimasi reliabilitas. Untuk mengestimasi koefisien reliabilitas dilakukan dengan bantuan software SPSS 21.0 for windows atau dengan menggunakan rumus Alpha Cronbach (Reynolds, Livingston, \& Willson, 2010, p.103) yaitu sebagai berikut:

$$
r_{x x^{\prime}}=\frac{k}{k-1}\left[1-\frac{\sum S D_{i}^{2}}{S D^{2}}\right]
$$

Keterangan:

$r_{x x^{\prime}}:$ Koefisien Alpha Cronbach

$k$ : Banyaknya item tes

$S D_{i}^{2}$ : Varian skor siswa pada item tertentu

$S D^{2}$ : Varians skor total

Setelah diperoleh koefisien realibilitas instrumen dengan rumus Alpha Cronbach, dilakukan penghitungan standar error measurement (SEM) untuk masing-masing instrument dengan menerapkan rumus berikut (Nitko \& Brookhart, 2011, p.76).

$$
S E M=S D_{x} \sqrt{1-r_{x x^{\prime}}}
$$

Keterangan:

SEM: standar erorr of measurement

$S D_{x}:$ standard deviation 
$r_{x x^{\prime}}:$ koefisien reliabilitas

Hasil estimasi reliabilitas instrumen penelitian dan nilai SEM untuk masing-masing variabel diberikan pada Tabel 1.

Tabel 1. Hasil Estimasi Reliabilitas dan SEM Instrumen Pengumpulan Data

\begin{tabular}{lcc}
\hline \multicolumn{1}{c}{ Instrumen } & $\boldsymbol{r}_{x x^{\prime}}$ & SEM \\
\hline - Angket self-efficacy & 0,900 & 3,626 \\
Tes kemampuan berpikir kritis & & \\
- Pretest & 0,889 & 1,663 \\
- Posttest & 0,755 & 2,389 \\
Tes prestasi belajar & & \\
- Pretest & 0,721 & 1,942 \\
- Posttest & 0,703 & 1,992 \\
\hline
\end{tabular}

Data yang akan dianalisis dalam penelitian ini meliputi skor prestasi belajar, berpikir kritis dan self-efficacy siswa. Sesuai dengan rumusan masalah, ada 3 hipotesis penelitian yang akan diuji. Hipotesis pertama terkait dengan efektivitas pendekatan PBL setting TTW. Hipotesis kedua adalah efektivitas pendekatan PBL setting TPS. Sedangkan hipotesis ketiga yang diuji adalah terkait perbedaan keefektifan antara pendekatan PBL setting TTW dan PBL setting TPS.

Pengujian hipotesis dilakukan dengan menggunakan multivariate analyze of varians (MANOVA) dan one sample t-test. Untuk menguji keefektifan treatment yang diberikan menggunakan one sample t-test (Tatsuoka, 1988, p.77) dengan menggunakan rumus sebagai berikut:

$$
t=\frac{\bar{X}-\mu_{0}}{\frac{S}{\sqrt{n}}}
$$

Keterangan:

$\bar{X}=$ nilai rata-rata yang diperoleh,

$\mu_{0}=$ nilai yang dihipotesiskan,

$S=$ standar deviasi sampel,

$n=$ banyak anggota sampel.

Analisis data dilakukan dengan bantuan SPSS 21. Adapun nilai yang dihipotesiskan $\left(\mu_{0}\right)$ adalah kriteria ketuntasan minimal (KKM) yang telah ditentukan, yakni 75 untuk prestasi belajar, 65 untuk kemampuan berpikir kritis dan 77 untuk self-efficacy siswa. PBL setting TTW dan $P B L$ setting TPS efektif ditinjau dari ditinjau dari prestasi belajar, kemampuan berpikir kritis dan self-efficacy jika hasil pengujian menunjukkan rata-rata skor yang diperoleh siswa lebih dari 75 untuk prestasi belajar, 65 untuk kemampuan berpikir kritis dan 77 untuk self-efficacy.
Selanjutnya, untuk menguji ada tidaknya perbedaan kondisi awal siswa dan perbedaan keefektifan antara pendekatan PBL setting TTW dan PBL setting TPS dilakukan dengan uji multivariat (MANOVA). Pengujian Hipotesis diuji dengan rumus berikut:

$$
\begin{gathered}
\quad F=\frac{n_{1}+n_{2}-p-1}{\left(n_{1}+n_{2}-2\right) p} T^{2}, \\
\text { Dimana } T^{2}=\frac{n_{1} x n_{2}}{n_{1}+n_{2}}\left(\bar{y}_{1}-\bar{y}_{2}\right)^{\prime} S^{-1}\left(\bar{y}_{1}-\bar{y}_{2}\right)
\end{gathered}
$$

(Stevens, 2009, p. 151)

Keterangan:

$T^{2}=$ Hotelling's Trace

$n_{l}=$ banyak anggota sampel I

$n_{2}=$ banyak anggota sampel II

$\overline{y_{1}}-\overline{y_{2}}=$ mean vektor

$S^{-1}=$ invers matriks kovariansi.

$p=$ banyaknya variabel dependen

Jika nilai signifikansi yang diperoleh lebih besar dari 0,05 , berarti tidak terdapat perbedaan prestasi belajar, kemampuan berpikir kritis dan self-efficacy pada kedua kelompok, baik sebelum maupun setelah perlakuan.

Sebelum melakukan uji hipotesis, terlebih dahulu dilakukan uji asumsi yaitu uji normalitas dan uji homogenitas, baik untuk data sebelum maupun setelah perlakuan. Uji normalitas dilakukan dengan uji normalitas multivariat (menggunakan jarak Mahalanobis) dan uji normalitas univariat (menggunakan uji KolmogorovSmirnov). Pengujian normalitas multivariat dilakukan dengan menggunakan jarak Mahalanobis dengan kriteria keputusan bahwa data dikatakan berdistribusi normal jika sekitar sekitar 50\% nilai $d_{i}^{2}<X^{2}{ }_{0,5(p)}$ (Johnson \& Wichern, 2007, p.183). Uji homogenitas matriks varianskovarians dilakukan dengan menggunakan uji Box's $M$ dengan kriteria keputusan bahwa data dikatakan homogen jika nilai signifikansi $F$ lebih besar dari 0,05 .

\section{HASIL PENELITIAN}

Data hasil tes prestasi belajar pada kedua kelompok dengan pendekatan PBL setting TTW maupun PBL setting TPS dideskripsikan berdasarkan nilai pretest dan posttest. Berdasarkan Tabel 2, terlihat bahwa sebelum perlakukan nilai maksimum prestasi belajar (pretest) yang diperoleh adalah 70 dan nilai terendah yang diperoleh adalah 20. Rata-rata nilai tes prestasi belajar siswa sebelum perlakuan pada kelompok eksperimen 1 adalah 49,67 dan pada kelompok eksperimen 2 adalah 51,17. 
Jurnal Riset Pendidikan Matematika, 5 (1), 2018 - 121

Wahyu Hardiyanto, Rusgianto Heri Santoso

Tabel 2. Statistik Deskriptif Prestasi Belajar

\begin{tabular}{lcccc}
\hline \multirow{2}{*}{ Deskripsi } & \multicolumn{5}{c}{ Kelas } \\
\cline { 2 - 5 } & \multicolumn{2}{c}{ PBLTTW } & \multicolumn{3}{c}{ PBLTPS } \\
\cline { 2 - 5 } & Pretest & Posttest & Pretest & Posttest \\
\hline Rata-rata & 49,67 & 82,167 & 51,17 & 81 \\
Std. dev & 11,37 & 14,895 & 9,531 & 14,17 \\
Skor ideal & & & & \\
• Maksimum & 100 & 100 & 100 & 100 \\
- Minimum & 0 & 0 & 0 & 0 \\
Skor aktual & & & & \\
- Maksimum & 70 & 100 & 70 & 100 \\
- Minimum & 30 & 55 & 20 & 40 \\
\hline
\end{tabular}

Setelah diberikan perlakukan, nilai ratarata prestasi belajar (post-test) siswa pada kelompok eksperimen 1 adalah 82,67 sedangkan pada kelompok eksperimen 2 nilai rata-rata yang diperoleh adalah 8. Dari kedua kelompok eksperimen tersebut, nilai maksimum setelah perlakuan yang dicapai adalah 100 .

Tabel 3. Statistik Deskriptif Kemampuan Berpikir Kritis

\begin{tabular}{lcccc}
\hline \multirow{2}{*}{ Deskripsi } & \multicolumn{4}{c}{ Kelas } \\
\cline { 2 - 5 } & \multicolumn{3}{c}{ PBLTTW } & \multicolumn{3}{c}{ PBLTPS } \\
\cline { 2 - 5 } & Pretest & Posttest & Pretest & Posttest \\
\hline Rata-rata & 55,7 & 74,2 & 58,5 & 75,8 \\
Std. dev & 27,4 & 25,5 & 11,8 & 25,5 \\
$\begin{array}{l}\text { Skor ideal } \\
\bullet\end{array}$ & & & & \\
• maksimum & 100 & 100 & 100 & 100 \\
• minimum & 00,00 & 00,00 & 00,00 & 00,00 \\
Skor aktual & & & & \\
$\bullet$ maksimum & 90 & 100 & 75 & 100 \\
$\bullet$ minimum & 10 & 30 & 35 & 30 \\
\hline
\end{tabular}

Berdasarkan data statistik deskriptif pada Tabel 3, diperoleh informasi bahwa dari kedua kelompok eksperimen terlihat nilai maksimum kemampuan berpikir kritis yang diperoleh adalah 90 dan nilai terendah yang diperoleh adalah 10 (sebelum perlakukan). Rata-rata nilai tes kemampuan berpikir kritis sebelum perlakuan pada kelompok eksperimen 1 adalah 55,7 dan pada kelompok eksperimen 2 adalah 58,5.

Setelah diberikan perlakukan, nilai ratarata kemampuan berpikir kritis kelompok eksperimen 1 adalah 74,2 sedangkan pada kelompok eksperimen 2 adalah 75,8. Sedangkan nilai maksimum kemampuan berpikir kritis yang dicapai dari kedua kelompok eksperimen adalah 100.

Selanjutnya, berdasarkan Tabel 4, ratarata self-efficacy siswa sebelum perlakuan pada kelompok eksperimen 1 adalah 62,97 sedangkan pada kelompok eksperimen 2 adalah 64,34. Setelah dilakukan perlakukan rata-rata self-efficacy siswa mengalami kenaikan. Pada kelas VIII-G rata-rata self-efficacy siswa setelah perlakukan adalah 87,7, sedangkan pada kelas VIII-H ratarata self-efficacy siswa adalah 84,73.

Tabel 4. Deskripsi Self-Efficacy Siswa

\begin{tabular}{lcccc}
\hline \multirow{2}{*}{ Deskripsi } & \multicolumn{4}{c}{ Kelas } \\
\cline { 2 - 5 } & \multicolumn{2}{c}{ PBLTTW } & \multicolumn{2}{c}{ PBLTPS } \\
\cline { 2 - 5 } & Pretest & Posttest & Pretest & Posttest \\
\hline Rata-rata & 62,97 & 87,8 & 64,34 & 84,73 \\
Std. dev & 7,17 & 10,92 & 5,49 & 9,34 \\
$\begin{array}{l}\text { Skor ideal } \\
\text { • Maksimum }\end{array}$ & 115 & 115 & 115 & 115 \\
• Minimum & 23 & 23 & 23 & 23 \\
Skor aktual & & & & \\
• Maksimum & 77 & 110 & 77 & 115 \\
• Minimum & 52 & 69 & 54 & 75 \\
\hline
\end{tabular}

Selanjutnya, sebagaimana yang disebutkan pada metode penelitian, bahwa sebelum melakukan uji hipotesis dilakukan uji asumsi normalitas dan homogenitas. Hasil uji normalitas disajikan pada Tabel 5.

Tabel 5. Hasil Uji Normalitas Multivariat

\begin{tabular}{lll}
\hline \multicolumn{1}{c}{ Kelas } & $\boldsymbol{d}_{\boldsymbol{i}}^{\mathbf{2}}$ Pretest & $\boldsymbol{d}_{\boldsymbol{i}}^{\mathbf{2}}$ Posttest \\
\hline PBLTTW & $46,67 \%$ & $53,34 \%$ \\
PBLTPS & $46,67 \%$ & $46,67 \%$ \\
\hline
\end{tabular}

Tabel 5 menunjukkan bahwa sekitar 50\% data mempunyai nilai $d_{i}^{2}<X^{2}{ }_{0,5}$ (3). Hal tersebut menunjukkan bahwa sampel berasal dari populasi yang berdistribusi normal multivariat.

Tabel 6. Hasil Uji Homogenitas

\begin{tabular}{lcc}
\hline & Pretest & Postest \\
\hline Box's $M$ & 27,834 & 2.333 \\
Sig & 0,000 & 0,900 \\
\hline
\end{tabular}

Berdasarkan Tabel 6 diperoleh informasi bahwa nilai signifikansi lebih besar dari 0,05 yaitu 0,900 untuk data setelah perlakuan. Namun terlihat bahwa nilai signifikasi yang diperoleh pada sebelum perlakuan adalah 0,000 dimana $0,000<0,05$. Hal ini menunjukkan bahwa matriks varians-kovarians untuk data sebelum perlakuan tidak homogen. Namun hal ini tidak menjadi masalah yang berarti. Jika sampel dalam jumlah kecil dan matriks varians-kovarians tidak homogen, maka hal ini hanya akan memberi pengaruh yang kecil (Ghozali, 2013, p.320).

Selain uji homogenitas, dilakukan pula uji normalitas univariat yang disajikan pada Tabel 7. 
Jurnal Riset Pendidikan Matematika, 5 (1), 2018 - 122

Wahyu Hardiyanto, Rusgianto Heri Santoso

Tabel 7. Hasil Uji Normalitas Univariat

\begin{tabular}{lll}
\hline \multirow{2}{*}{\multicolumn{1}{c}{ Aspek }} & \multicolumn{2}{c}{ Sig. } \\
\cline { 2 - 3 } & PBLTTW & PBLTPS \\
\hline Prestasi belajar & 0,206 & 0,894 \\
Kemampuan berpikir kritis & 0,192 & 0,153 \\
Self-efficacy & 0,511 & 0,326 \\
\hline
\end{tabular}

Berdasarkan Tabel 7, terlihat bahwa nilai signifikansinya lebih besar dari 0,05. Berdasarkan hal tersebut dapat diambil kesimpulan bahwa asumsi normalitas univariat terpenuhi.

Tabel 8. Hasil Uji Homogenitas Varians

\begin{tabular}{lll}
\multicolumn{1}{c}{ Aspek } & \multicolumn{1}{c}{ F } & \multicolumn{1}{c}{ Sig } \\
\hline Prestasi Belajar & 0,0748 & 0,391 \\
Kemampuan Berpikir Kritis & 0,006 & 0,940 \\
Self-Efficacy & 2,069 & 0,156 \\
\hline
\end{tabular}

Berdasarkan Tabel 8 dapat dilihat bahwa signifikansi dari prestasi belajar, berpikir kritis dan self-efficacy siswa lebih dari 0,05 sehingga dapat disimpulkan bahwa pada taraf nyata 0,05 varians kedua kelompok homogen.

Tabel 9. Rangkuman Hasil Analisis Multivariat Data Sebelum Perlakuan

\begin{tabular}{cccc}
\hline Effect & Value & $\boldsymbol{F}$ & Sig \\
\hline Hotelling's Trace & 0,021 & $0,393^{\mathrm{b}}$ & 0,758 \\
\hline
\end{tabular}

Berdasarkan hasil analisis pada Tabel 9, diperoleh nilai Hotelling's Trace adalah 0,021 dengan nilai signifikansi 0,758 . Dikarenakan nilai signifikansinya lebih dari 0,05 maka Ho diterima, maka dapat disimpulkan tidak terdapat perbedaan kemampuan awal antara pendekatan PBL setting TTW dengan PBL setting TPS ditinjau dari prestasi belajar, kemampuan berpikir kritis dan self-efficacy siswa.

Selanjutnya dilakukan uji hipotesis, untuk mengetahui keefektifan dari pendekatan problem-based learning setting think talk write dengan problem-based learning setting think pair share ditinjau dari prestasi belajar, kemampuan berpikir kritis dan self-efficacy siswa.

Tabel 10. Hasil Uji One Sample t-test

\begin{tabular}{lcccc}
\hline \multirow{1}{*}{ Aspek } & \multicolumn{2}{c}{ PBLTTW } & \multicolumn{2}{c}{ PBLTPS } \\
\cline { 2 - 5 } & $\mathbf{t}$ & $\begin{array}{l}\text { Sig.(2- } \\
\text { tailed })\end{array}$ & $\mathbf{t}$ & $\begin{array}{l}\text { Sig.(2- } \\
\text { tailed) }\end{array}$ \\
\hline Prestasi belajar & 2,66 & 0,012 & 2,320 & 0,028 \\
Kemampuan & 1,966 & 0,059 & 2,324 & 0,027 \\
berpikir kritis & 5,418 & 0,000 & 4,535 & 0,000 \\
Self-efficacy & 5,
\end{tabular}

Pada Tabel 10 dapat dilihat bahwa nilai signifikansi untuk variabel berpikir kritis, kemampuan berpikir kritis dan self-efficacy siswa pada kedua kelompok eksperimen kurang dari
0,05 . Oleh karena itu, disimpulkan bahwa pendekatan problem-based learning setting think talk write dan problem-based learning setting think pair share efektif ditinjau dari prestasi belajar, kemampuan berpikir kritis dan selfefficacy siswa.

Tabel 11. Rangkuman Hasil Analisis Multivariat Data Setelah Perlakuan

\begin{tabular}{cccc}
\hline Effect & Value & $\boldsymbol{F}$ & Sig \\
\hline Hotelling's Trace & 0,038 & $0,731^{\mathrm{b}}$ & 0,549 \\
\hline
\end{tabular}

Berdasarkan uji MANOVA pada Tabel 11 diperoleh hasil nilai Hotelling's Trace adalah 0,038 dengan nilai signifikansi 0,549 . Dikarenakan nilai signifikansinya lebih dari 0,05 maka dapat disimpulkan tidak terdapat perbedaan keefektifan antara pendekatan problem-based learning setting think talk write dan problembased learning setting think pair share ditinjau dari prestasi belajar, kemampuan berpikir kritis dan self-efficacy siswa.

\section{Pembahasan}

\section{Keefektifan Problem-Based Learning (PBL) setting Think Talk Write (TTW)}

Pembelajaran dengan pendekatan problem-based learning (PBL) setting think talk write (TTW) efektif ditinjau dari prestasi belajar siswa. Hasil tersebut diperoleh melalui serangkaian kegiatan dalam PBL yang mendorong siswa untuk mengkonstruksi pengetahuannya sehingga siswa lebih memahami apa yang mereka pelajari. Sehingga akan berpengaruh terhadap prestasi belajar siswa, melalui pendekatan problem-based learning (PBL) dapat membantu siswa berprestasi rendah. Hal tersebut sesuai dengan hasil penelitian yang dilakukan oleh Fatade, Mogari, Arigbabu (2013), dan Farhan, \& Retnawati (2011).

Pembelajaran dengan pendekatan problem-based learning (PBL) setting think talk write (TTW) efektif ditinjau dari kemampuan berpikir kritis. Hal tersebut sesuai dengan penelitian Karaduman (2013). Kegiatan dalam PBL memungkinkan siswa mengembangkan kemampuan berpikir kritis. Serangkaian kegiatan dalam PBL adalah siswa diberikan masalah, dan dari masalah tersebut siswa belajar untuk berpikir, menentukan informasi-informasi yang sesuai dan mengambil keputusan untuk menyelesaikan masalah melalui investigasi autentik. Selain itu, PBL dapat dipergunakan untuk mengembangkan kemampuan berpikir tingkat tinggi yaitu berpikir kritis dan kreatif melalui serangkaian kegiatan 
mempertimbangkan informasi dan bukti untuk mendukung keputusan yang dibuat (Happy, \& Widjajanti, 2014; Trop, \& Sage, 2009, p.18).

Pembelajaran dengan pendekatan problem-based learning (PBL) setting think talk write (TTW) efektif ditinjau dari self-efficacy siswa. Hal tersebut dikarenakan selama proses pembelajaran siswa dapat berpartisipasi aktif melalui kegiatan diskusi kelompok. Pada setiap kelompok terlihat adanya proses berbagi pengetahuan dimana jika terdapat siswa yang belum memahami materi dan permasalahan dalam LKS, maka siswa dapat saling berdiskusi. Adanya sistem presentasi kelas dalam proses pembelajaran, sangat memotivasi para siswa untuk belajar lebih giat dan serius. Misalnya ketika guru memanggil siswa untuk mempresentasikan hasil diskusi kelompoknya di depan kelas, maka semua siswa mau tidak mau harus siap untuk maju mewakili kelompoknya. Secara tidak langsung, model pembelajaran ini akan menambahkan rasa yakin terhadap kemampuan diri untuk bertanggung jawab pada setiap siswa terhadap kelompoknya.

\section{Keefektifan Problem-Based Learning (PBL) setting Think Pair Share (TPS)}

Berdasarkan hasil uji hipotesis diperoleh informasi bahwa nilai one sampel t-test untuk hipotesis keefektifan pembelajaran dengan pendekatan problem-based learning (PBL) setting think pair share (TPS) ditinjau dari aspek prestasi belajar matematika memiliki nilai $t$ sebesar 2,320 dengan nilai signifikasi sebesar 0,028 . Hal ini mengindikasikan bahwa pembelajaran dengan pendekatan problem-based learning (PBL) setting think pair share (TPS) efektif ditinjau dari aspek prestasi belajar matematika siswa.

Hasil penelitian ini sejalan dengan teori yang mengungkapkan bahwa pembelajaran dengan pendekatan problem-based learning (PBL) setting tipe think pair share (TPS) efektif ditinjau dari aspek prestasi belajar matematika siswa. Besar kemungkinan yang menyebabkan pembelajaran dengan pendekatan problem-based learning setting think pair share efektif pada aspek prestasi belajar dikarenakan siswa diberikan permasalahan nyata pada awal pembelajaran. Sebelum siswa memulai menyelesaikan permasalahan secara mandiri yang terdapat pada LKS, guru terlebih dahulu memastikan bahwa masalah yang diberikan sudah dipahami oleh siswa.

Kemudian dilanjutkan dengan bekerja sama secara berpasangan dengan baik yakni saling berdiskusi dalam mempelajari serta me- mahami isi dari LKS. Hasil dari diskusi yang dilakukan dengan pasangan kelompok tadi kemudian di-share dengan teman dengan mempresentasikannya didepan kelas. Peran guru adalah memberikan motivasi serta memantau jalannya proses pembelajaran agar dalam pelaksanaan pembelajaran. Aktivitas belajar siswa yang dilakukan mengalami peningkatan pada setiap pertemuan serta dapat memberikan pemahaman yang mendalam terhadap materi yang dipelajari.

Rangkaian kegiatan dalam pembelajaran dengan pendekatan problem-based learning (PBL) dengan menggunakan setting pembelajaran kooperatif tipe think pair share (TPS) juga memperlihatkan bahwa siswa tidak hanya terlibat pada awal pembelajaran melainkan juga terlibat sampai akhir pembelajaran. Selain itu rangkaian kegiatan siswa dalam mengeksplorasi masalah hingga menganalisis dan mengevaluasi pemecahan masalah yang dilakukan secara berpasangan. Artinya jawaban yang diberikan siswa untuk setiap pertanyaan yang terdapat pada LKS merupakan hasil kerja kelompok yang diperoleh secara berpasangan. Hal inilah yang menjadi alasan mengapa pembelajaran dengan pendekatan problem-based learning (PBL) setting think pair share (TPS) efektif ditinjau dari aspek prestasi belajar matematika siswa.

Selain itu, hasil uji one sample t-test menunjukkan bahwa nilai $t$ untuk aspek kemampuan berpikir kritis adalah sebesar 2,324 dengan signifikansi 0,027 . Hasil ini mengindikasikan bahwa pembelajaran dengan pendekatan problem-based learning (PBL) setting think pair share (TPS) efektif ditinjau dari aspek kemampuan berpikir kritis. Hal ini dikarenakan dalam pembelajaran dengan pendekatan problem-based learning (PBL) setting think pair share (TPS) siswa dituntut untuk menyelesaikan masalahmasalah yang diberikan juga melatih siswa belajar untuk menyajikan kembali suatu informasi kedalam bentuk gambar melalui pemodelan matematika dari soal permasalahan pada LKS. Soal permasalahan yang diberikan sesuai dengan materi yang digunakan dalam pembelajaran. Dengan memberikan permasalahanpermasalahan dengan karakter seperti itu, secara kontinue selama proses pembelajaran telah mengajarkan siswa untuk merefleksikan pemahaman mereka terhadap suatu permasalahan. Kemampuan berpikir kritis siswa dalam memahami wacana suatu permasalahan tentunya berbeda-beda. Untuk itu melalui masalah-masalah nyata yang ada didalam Problem Based Learn- 
ing melalui setting TPS, siswa diberi ruang untuk belajar mengungkapkan kembali ide-ide dasar yang mereka miliki berdasarkan pemahaman mereka terhadap suatu permasalahan yang telah mereka dapat.

Selain itu, berdasarkan hasil uji one sample t-test diperoleh informasi bahwa nilai $t$ untuk hipotesis keefektifan pembelajaran dengan pendekatan problem-based learning (PBL) setting think pair share (TPS) ditinjau dari aspek self-efficacy siswa adalah sebesar 4,535 dengan signifikansi 0,000 . Hasil ini mengindikasikan bahwa pembelajaran dengan pendekatan problem-based learning (PBL) setting think pair share (TPS) efektif ditinjau dari aspek selfefficacy siswa.

Perbedaan Keefektifan Pendekatan ProblemBased Learning (PBL) setting Think Talk Write (TTW) dan Think Pair Share (TPS)

Berdasarkan hasil uji hipotesis terhadap data setelah pemberian perlakuan diperoleh nilai $F$ sebesar 0,713 dengan signifikansi 0,549. Hal ini mengindikasikan bahwa tidak terdapat perbedaan keefektifan pembelajaran dengan pendekatan problem-based learning (PBL) setting pembelajaran kooperatif tipe think talk write (TTW) dan pembelajaran dengan pendekatan problem-based learning (PBL) setting pembelajaran kooperatif tipe think pair share (TPS) ditinjau dari aspek prestasi belajar, kemampuan berpikir kritis, dan self-efficaci siswa.

Adapun faktor yang diindikasikan penyebab tidak terdapat perbedaan antara kedua kelas adalah pada kedua pembelajaran pembelajaran dengan pendekatan problem-based learning (PBL) setting think talk write (TTW) dan pembelajaran dengan pendekatan problem-based learning (PBL) setting think pair share (TPS) guru belum dapat menjadi fasilitator sepenuhnya. Guru masih banyak berperan dalam membantu siswa untuk mengarahkan dan membimbing siswa. Hal tersebut terjadi karena siswa belum terbiasa dengan proses pembelajaran yang mengkolaborasikan PBL dengan TTW maupun TPS sehingga siswa memerlukan waktu untuk beradaptasi.

Kemungkinan lain yang diduga menjadi penyebab tidak terdapatnya perbedaan keefektifan pembelajaran dengan pendekatan problembased learning (PBL) setting think talk write (TTW) dan pembelajaran dengan pendekatan problem-based learning (PBL) setting think pair share (TPS) adalah karena kedua pendekatan tersebut menekankan pada kolaborasi dan diskusi antar anggota kelompok. Sehingga, dalam penerapannya pada kedua kelompok eksperimen tersebut siswa sama-sama aktif saling berinteraksi, bertukar informasi dan aktif mengkonstruksikan pengetahuannya berdasarkan informasi dan pengalaman dialaminya.

Hal lain yang dapat diindikasikan ketidaksesuaian hasil penelitian dengan hipotesis penelitian diduga karena belum maksimalnya aktivitas siswa baik pada pembelajaran dengan pendekatan problem-based learning (PBL) setting think talk write (TTW) dan pembelajaran dengan pendekatan problem-based learning (PBL) setting think pair share (TPS).

Meskipun tidak terdapat perbedaan keefektifan antara pembelajaran dengan pendekatan problem-based learning (PBL) setting think talk write (TTW) dan pembelajaran dengan pendekatan problem-based learning (PBL) setting think pair share (TPS), namun kedua perlakuan tersebut efektif ditinjau dari prestasi belajar, kemampuan berpikir kritis, dan self-efficacy siswa. Sehingga dapat disimpulkan baik pembelajaran dengan pendekatan problem-based learning (PBL) setting think talk write (TTW) maupun pembelajaran dengan pendekatan problem-based learning (PBL) setting think pair share (TPS) dapat dipergunakan untuk mengembangkan prestasi belajar siswa, kemampuan berpikir kritis, dan self-efficacy siswa.

\section{SIMPULAN DAN SARAN}

Berdasarkan hasil pengujian hipotesis dan pembahasan yang telah dipaparkan, diperoleh kesimpulan sebagai berikut. Pertama, pendekatan problem-based learning setting think talk write maupun problem-based learning setting think pair share efektif ditinjau dari prestasi belajar, kemampuan berpikir kritis dan selfefficacy siswa. Kedua, tidak terdapat perbedaan keefektifan yang signifikan antara pendekatan problem-based learning setting think talk write maupun problem-based learning setting think pair share ditinjau dari prestasi belajar siswa, kemampuan berpikir kritis, dan self-efficacy siswa.

Berdasarkan hasil penelitian ini, maka peneliti merekomendasikan beberapa hal. Pertama, guru dapat menerapkan pendekatan problembased learning setting think talk write maupun problem-based learning setting think pair share untuk meningkatkan prestasi belajar, kemampuan berpikir kritis dan self-efficacy siswa. Kedua, masih perlu dilakukan penelitian secara lebih mendalam dan dalam waktu yang lebih panjang 
sehingga dapat terlihat efek dari penerapan pendekatan PBL dalam proses pembelajaran terhadap kemampuan yang dimiliki siswa. Penelitian yang dilaksanakan dalam waktu lebih panjang dimungkinkan dapat memberikan pengaruh yang lebih baik untuk siswa.

\section{DAFTAR PUSTAKA}

Arends, R. I. (2012). Learning to teach. ( $9^{\text {th }}$ ed.). New York, NY: McGraw-Hill.

Bandura, A. (Ed.). (1995). Self-efficacy in changing societies. New York, NY: Cambridge University Press.

Basham, Irwin, Nardone, and Wallace. (2011). Critical thinking a student's introduction. New York, NY: McGraw-Hill.

Djidu, H., \& Jailani. (2016). Fostering student's higher-order thinking skill through problem-based learning in calculus. In Proceeding of $3 r d$ International Conference on Research, Implementation and Education of Mathematics and Science (pp. 127-130). Yogyakarta: Faculty of Mathematics and ScienceYogyakarta State University. Retrieved from http://seminar.uny.ac.id/icriems/sites/seminar.uny.ac.id.icriems/files/prosiding/ME-19.pdf

Djidu, H., \& Jailani, J. (2017). Aktivitas pembelajaran matematika yang dapat melatih kemampuan berpikir tingkat tinggi siswa. PRISMA, Prosiding Seminar Nasional Matematika, 1(1), 312-321. Retrieved from https://journal.unnes.ac.id/sju/index.php/prisma/article/view/21 614

Farhan, M \& Retnawati, H. (2014). The effectiveness of PBL and IBL in terms of achievement, mathematical representation capabilities, and motivation. Jurnal Riset Pendidikan Matematika, 1 (2), 227-240.

Fatade, A. O., Mogari D., \& Arigbabu A. A (2013). Effect of problem-based learning on senior secondary school students' achievements in further mathematics. Acta Didactica Napocensia, 6(3), 27-44.

Ghozali, I. (2013). Aplikasi analisis multivariate dengan program IBM SPSS (cetakan ke7). Semarang: Badan Penerbit Universitas Diponegoro.

Happy, N. \& Widjajanti, B.W. (2014). Keefektifan PBL ditinjau dari kemampuan berpikir kritis dan kreatif matematis, serta self-esteem siswa SMP. Jurnal Riset Pendidikan Matematika, 1 (1), 48-57.

Hendriana, H. (2009). Pembelajaran dengan pendekatan metaphorical thinking untuk meningkatkan kemampuan pemahaman matematik, komunikasi matematik dan kepercayaan diri siswa sekolah menengah pertama. Disertasi Sekolah Pasca Sarjana UPI. Bandung: Tidak diterbitkan.

Jailani, J., Sugiman, S., \& Apino, E. (2017). Implementing the problem-based learning in order to improve the students' HOTS and characters. Jurnal Riset Pendidikan Matematika, 4(2), 247-259. https://doi.org/10.21831/jrpm.v4i2.17674

Johnson, R. A. \& Wichern, D. W. (2007). Applied Multivariate Statistical Analysis. Upper Saddle River, NJ: Pearson Prentice-Hall, Inc.

Karaduman, G. B. (2013). The relationship between prospective primary mathematics teachers attitudes towards Problem-Based Learning and their studying tendencies. International Journal on New Trends in Education and Their Implications, 4, 1309-6249.

Mason, M. (2008). Critical thinking and learning. Malden, MA: Blackwell Publishing.

Mendikbud RI. (2014). Peraturan Menteri Pendidikan dan Kebudayaan Republik Indonesia Nomor 58 Tahun 2014 tentang Kurikulum SMP. Jakarta: Kemendikbud RI.

Mokhtar, M. Z., Tarmizi, R. A., Ayub, A. F. M., \& Nawawi, M. D. H. (2013). Motivation and performance in learning calculus through problem-based learning. International Journal of Asian Social Science, 3(9), 1999-2005. Retrieved from http://www.aessweb.com/pdf-files/ljasssi-3(9)-1999-2005.pdf

Nezami, N. R., Asgari, M. \& Dinarvand, H. (2013). The effect of cooperative learning on the critical thinking of high school students. Technical Journal of Engineering and Applied Sciences, 3(19): 2508-2514.

Ningrum, R. K. (2017). Meningkatkan kemampuan komunikasi matematis siswa menggunakan problem based learning berbasis flexible mathematical thinking. 
PRISMA, Prosiding Seminar Nasional Matematika, 1(1), 213-222. Retrieved from

https://journal.unnes.ac.id/sju/index.php/p risma/article/view/21620

Nitko, A. J. \& Brookhart, S. M. (2011). Educational assessment of students. Upper Saddle River, NJ: Pearson-Merrill Prentice Hall.

Retnawati, H., Djidu, H., Kartianom, Apino, E., \& Anazifa, R. D. (2018). Teachers' knowledge about higher-order thinking skills and its learning strategy. Problem of Education in the 21st Century, 76(2), 215-230.

Retnawati, H., Kartowagiran, B., Arlinwibowo, J., \& Sulistyaningsih, E. (2017). Why are the mathematics national examination items difficult and what is teachers' strategy to overcome it? International Journal of Instruction, 10(3), 257-276. https://doi.org/10.12973/iji.2017.10317a.

Reynolds, C. R, Livingston, R. B., \& Wilson, V. (2010) Measurement and assessment in education. ( $2^{\text {nd }}$ ed.). Upper Saddle River, NJ: Pearson Education, Inc.
Rohaeti, E. E. (2008). Pembelajaran dengan pendekatan eksplorasi untuk mengembangkan kemampuan berpikir kritis dan kreatif matematik siswa sekolah menengah pertama. Disertasi: tidak diterbitkan. Sekolah Pasca Sarjana UPI.

Susanto, E., \& Retnawati, H. (2016). Perangkat pembelajaran matematika bercirikan PBL untuk mengembangkan HOTS siswa SMA. Jurnal Riset Pendidikan Matematika, 3(2), 189-197. https://doi.org/10.21831/jrpm.v3i2.10631.

Stevens, J. P. (2009). Applied multivariate statistics for sosial science $\left(5^{\text {th }} \mathrm{ed}\right)$. New York, NY: Routledge

Tan, O. S. (2003). Problem-based learning innovation: using problems to power learning in the $21^{\text {st }}$ Century. Singapore: Cengage Learning.

Tatsuoka, M. M. (1971). Multivariate analysis: Techniques for educational and psychological research. New york, NY: John Wiley \& Sons, Inc.

Trop, L., \& Sage, S. (2002). Problems as possibilities problem-based learning for $K$-16 education. ( $2^{\text {nd }}$ edition). Alexandria, VA: ASCD. 